\title{
Assessment of Embodied Energy and Carbon IV Oxide Emission of Concrete Containing Corncob Ash
}

\author{
Aliyu Abubakar ${ }^{*}$, Abbagana Mohammed, Duna Samson \\ Department of Civil Engineering, Faculty of Engineering Technology, Abubakar Tafawa Balewa University, Bauchi, Nigeria \\ Email address: \\ aabubakar24@atbu.edu.ng (A. Abubakar), agmohammed@atbu.edu.ng (A. Mohammed), dunamine@yahoo.com (D. Samson) \\ ${ }^{*}$ Corresponding author
}

To cite this article:

Aliyu Abubakar, Abbagana Mohammed, Duna Samson. Assessment of Embodied Energy and Carbon IV Oxide Emission of Concrete Containing Corncob Ash. International Journal of Sustainable and Green Energy. Vol. 10, No. 2, 2021, pp. 76-84.

doi: $10.11648 /$ j.ijrse.20211002.15

Received: June 10, 2021; Accepted: June 21, 2021; Published: June 26, 2021

\begin{abstract}
The purpose of this study is to assess the Embodied Energy (EE) and Carbon IV Oxide $\left(\mathrm{CO}_{2}\right)$ emissions saving potentials of Corn Cob Ash (CCA) as partial replacement of Ordinary Portland Cement (OPC) in concrete. Cement manufacture is energy intensive and contributes considerable amount of $\mathrm{CO}_{2}$ emissions into the atmosphere. Globally, Concrete is the most consumed man-made material and about $95 \%$ of $\mathrm{CO}_{2}$ emissions from a cubic meter of concrete are from cement manufacturing. In this study, the experimental plan was designed to carry out compressive strength, flexural strength, density and water absorption tests on the concrete using $0,5,10,15$ and 20\% CCA contents to replace OPC. Inventory method of analysis was used to determine the $\mathrm{EE}$ and $\mathrm{CO}_{2}$ emission for all the concrete mixes. The results indicated that the water absorption, density, compressive and flexural strength decreased with increase in CCA content and increased with curing period. The optimum blend was obtained at $10 \% \mathrm{CCA}$ and $90 \%$ OPC contents. The EE and $\mathrm{CO}_{2}$ emission decreased with increase in CCA contents. At $20 \%$ CCA content the EE was $2382 \mathrm{MJ} / \mathrm{m}^{3}$ which is $12.04 \%$ less than that of control samples. Also, $16.37 \%$ embodied $\mathrm{CO}_{2}$ emission saving was obtained for samples containing $20 \% \mathrm{CCA}$. The regression equations generated gave standard deviation, $\mathrm{S},<1.0$, P-value $<0.05$, T-statistics $>\mathrm{T} 24,0.05$ and F-statistics $>$ F1, 23, 0.05. All these indicated that there is good relationship between the predictors and the responses.
\end{abstract}

Keywords: Carbon IV Oxide Emission, Compressive Strength, Concrete, Corn Cob Ash, Embodied Energy

\section{Introduction}

The worldwide increasing demand for energy is one of the major causes for the unsustainable development of our Planet. Organization for Economic Co-operation and Development (OECD) reported that from 2007 to 2030 energy demand is projected to increase by about $40 \%$ which is about 15.24 billion tonnes of petroleum equivalent [1]. Concrete is considered as the world's most consumed man-made material. Every one tonne of concrete leads to $\mathrm{CO}_{2}$ emission which varies between 0.05 to 0.13 tonnes. About $95 \%$ of all $\mathrm{CO}_{2}$ emissions from a cubic meter of concrete are from cement manufacturing. The annual global production of concrete is about 4.54 billion tonnes. If the production of this building material remains at this frightening level, it is expected that about 3.5 billion tonnes of cement would be produced by the end of 2050 which amounts to doubling the $\mathrm{CO}_{2}$ emissions [2].
Energy used in concrete production includes EE in cement, energy used to extract and process aggregates, transportation energy, and energy used in the concrete plant. The EE of cement production contributes a large proportion of the total EE of concrete. The EE of structural components makes up about a quarter of the EE of all elements installed at the time of construction [3]. Also, process of cement production emits large amount of $\mathrm{CO}_{2}$ into the atmosphere, every tonne of cement produced releases approximately one tonne of $\mathrm{CO}_{2}$ into the atmosphere which is a major contributor for greenhouse effect and the global warming [4]. The calcination process is responsible for $50 \%$ of $\mathrm{CO}_{2}$ emissions, $45 \%$ due to burning fuel and $5 \%$ due to mining and transportation [5].

Olivier, Janssens-Maenhout, and Peters [6] reported that in $2015, \mathrm{CO}_{2}$ emissions generated by carbonate oxidation in the cement clinker production process, the main constituent of 
cement and the largest of non-combustion sources of $\mathrm{CO}_{2}$ from industrial manufacturing, contributed about $4.0 \%$ of the total global $\mathrm{CO}_{2}$ emissions while fuel combustion emissions of $\mathrm{CO}_{2}$ related to cement production are of approximately the same level, so, in total, cement production accounts for roughly $8 \%$ of the total global $\mathrm{CO}_{2}$ emissions. González and Navarro [7] estimated that the selection of building materials with low impacts can reduce $\mathrm{CO}_{2}$ emissions by up to $30 \%$. Therefore, partial replacement of OPC with supplementary cementitious materials such as CCA is expected to yield a significant reduction in $\mathrm{EE}$ and $\mathrm{CO} 2$ emissions.

According to the United Nation Centre for Human Settlement (UNCHS) [8], the main step that can be adopted to mitigate the consumption of energy and $\mathrm{CO}_{2}$ emission associated with construction materials is to reduce their total primary energy consumption. Increasing the efficiency of energy use in construction materials production is important for three reasons, apart from the obvious advantage of energy saving: it can help to make durable construction materials available at bearable costs; it will help to reduce the environmental degradation caused by the excessive use of biomass fuels; and it will also help to reduce the need for imported construction materials or production processes. The aim of energy analysis is to determine the total quantity of energy that should be taken from primary energy resources in order to produce a given material. The analysis also has to include the amount of energy expended in obtaining the raw materials and the energy used in transporting them to the factory. It should also include the energy used to produce and maintain the machinery used in the production process. The total energy calculated in this way is the energy embodied in that material [8].

\subsection{Corncob Ash}

Corncob is an agricultural by-product obtained from maize. It is the hard thick approximately cylindrical central core of maize (on which are borne the grains). The ash resulting from burning the corncob at elevated temperature $\left(450^{\circ} \mathrm{C}-650^{\circ} \mathrm{C}\right)$ is known as corn cob ash (CCA) and it has been classified as pozzolana [9].

CCA has pozzolanic properties and has been shown to chemically react with the calcium hydroxide released during the hydration process of cement to form cement compounds. Active pozzolanas gain their binding properties when they react with calcium hydroxide in cement in the presence of water. Studies showed that CCA improves the properties of cement materials, based on its pozzolanic properties $[10,11]$.

\subsection{Embodied Energy}

EE is the amount of energy consumed in all processes associated with the production of a material, from mining and processing of natural resources to manufacturing, transporting and then the delivery of the product [12]. It includes the direct and indirect energies consumed in processing the product. Direct energy is consumed in various on-site and off-site operations like construction, prefabrication, transportation and administration. Indirect energy is the energy used during the manufacturing of building materials, in the main process, upstream processes and downstream processes and during renovation, refurbishment, and demolition. This includes initial embodied energy, recurrent embodied energy and demolition energy [13].

Various approaches to measure EE employ different system boundaries and collect data from different sources, which could result in significantly different values of EE for the same product. System boundaries may range from a restrictive analysis of direct energy required for a particular process, to an expansive analysis including energy used by entire industrial input chains and society as a whole. Analyses may consider only purchased fossil fuel energy inputs, or may include renewable sources or combustible process by-products. Data may be direct measurements of energy used by a particular machine or factory, or may be aggregated for an entire industrial sector [14].

Basically there are four methods of measuring EE: process analysis, input-output analysis, hybrid analysis and inventory analysis. This research work uses the inventory method of analysis developed by Hammond and Jones at University of Bath $[15,16]$. They published an Inventory of Carbon and Energy (ICE), which is a database containing EE and $\mathrm{CO}_{2}$ values per functional unit of material (which could be in form of area $\left(\mathrm{m}^{2}\right)$, mass $(\mathrm{kg})$ or volume $\left(\mathrm{m}^{3}\right)$ for different common building materials. The data for this inventory was extracted from peer reviewed literature on the basis of a defined methodology and criteria. It is considered that the strict criteria used in the selection of source material for the creation of the ICE serve to significantly increase its accuracy and relevancy.

According to Berndt [17], there are several essentials which can reduce the environmental impact factor and $\mathrm{CO}_{2}$ intensity of concrete used for construction, which include maximizing the concrete durability, conservation of materials, use of waste and supplementing cementing materials and recycling of concrete. Partial replacement of cement with waste supplementary cementitious materials such as fly ash, ground granulated blast furnace slag, silica fume, rice husk ash and metakaolin not only improves the concrete durability and reduce the risk of thermal cracking in mass concrete but also emits less $\mathrm{CO}_{2}$ than cement.

In view of the above, this study is aimed at investigating the $\mathrm{EE}$ and $\mathrm{CO}_{2}$ emission saving potentials of CCA when used as partial replacement of cement in concrete.

\section{Materials and Methods}

\subsection{Materials}

Ordinary Portland cement (OPC) was used throughout the research. It has a consistency of $36 \%$, initial setting time of 43 minutes, final setting time of 492 minutes and specific gravity of 3.09. The tests were conducted in accordance with BS EN 196: 3 [18] and BS EN 197: 1 [19] specifications. 
The oxides composition of the OPC is presented in Table 1 The fine aggregate (sand) used was obtained from a stream at Bayara village along Bauchi-Dass road with maximum size of $4.75 \mathrm{~mm}$ and specific gravity of 2.63. The coarse aggregate used was crushed normal weight igneous rock aggregate with maximum size of $20 \mathrm{~mm}$ obtained from a quarry site in Bauchi. It has specific gravity of 2.65, aggregate crushing value of $14.5 \%$ and aggregate impact value of $7.64 \%$. The materials were tested in accordance with BS EN 1097: 6 [20], BS 812: 2 [21], BS 812: 110 [22] and BS EN 933: 1 [23] specifications. The corncobs used were collected from white floury maize variety and stored in polythene bags for about three months before burning. The CCA was produced using controlled burning process in a kerosene powered kiln at elevated temperature of about $500^{\circ} \mathrm{C}$. The resulting CCA was ground using mortar and pestle before sieving with $212 \mu \mathrm{m}$ sieve size. Figure 1 shows the flow diagram for the production of CCA while oxides composition of the CCA is presented in Table 1. The physical properties of the CCA determined were the specific gravity (2.27) and loose bulk density $\left(304 \mathrm{~kg} / \mathrm{m}^{3}\right)$. The water used was portable drinking water obtained from tap source, within the laboratory.

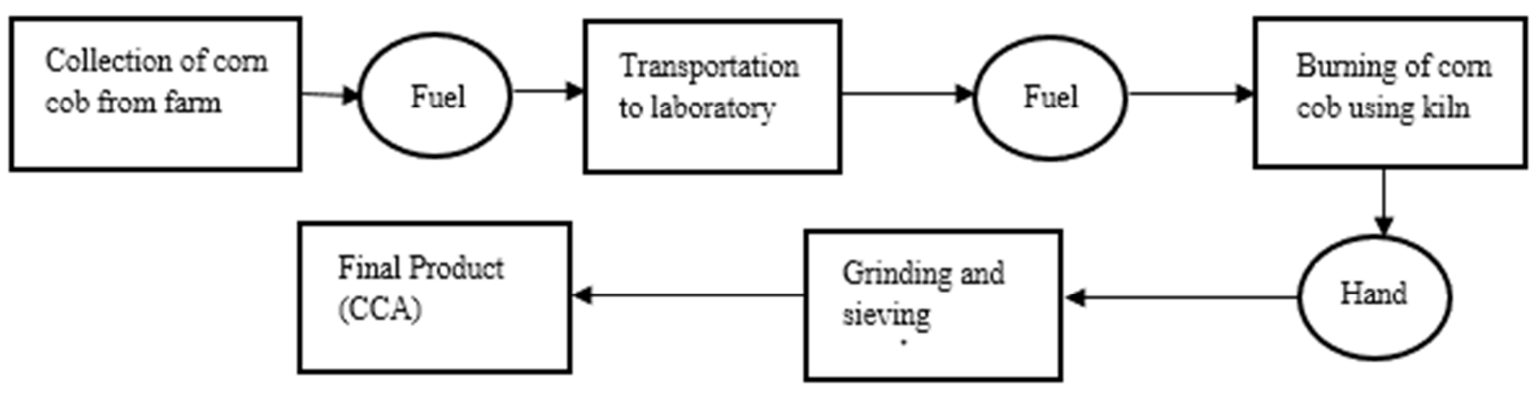

Figure 1. Flow diagram showing the process of CCA production.

Table 1. Percentage oxides composition of $O P C$ and $C C A$.

\begin{tabular}{lll}
\hline Oxides & OPC & CCA \\
\hline $\mathrm{SiO}_{2}$ & 20.7 & 66.4 \\
$\mathrm{Al}_{2} \mathrm{O}_{3}$ & 6.1 & 7.5 \\
$\mathrm{Fe}_{2} \mathrm{O}_{3}$ & 2.3 & 4.4 \\
$\mathrm{CaO}$ & 62.1 & 11.6 \\
$\mathrm{MgO}$ & 1.2 & 2.1 \\
$\mathrm{~K}_{2} \mathrm{O}$ & 1.0 & 4.9 \\
$\mathrm{Na}_{2} \mathrm{O}$ & 0.9 & 0.4 \\
$\mathrm{SO}_{3}$ & 1.6 & 1.1 \\
$\mathrm{LOI}$ & 1.0 & - \\
\hline
\end{tabular}

Grade 30 concrete was designed and mix ratio of 1: 1.41: 2.88 was obtained at water-to-cement ratio of 0.46 . The water content per cubic meter of concrete was $191.58 \mathrm{~kg}$, cement content was $416.47 \mathrm{~kg} / \mathrm{m}^{3}$, fine aggregate content was 589.15 and coarse aggregate content was $1200.04 \mathrm{~kg} / \mathrm{m}^{3}$. Five different mixes were designed using CCA of $0,5,10,15$ and 20 percent to replace OPC by weight. The samples were produced and cured by immersion in water according to BS EN 12390 part1 \& 2 specifications [24, 25]. Concrete cubes of size $100 \mathrm{~mm} \times 100 \mathrm{~mm} \times 100 \mathrm{~mm}$ and beams of size $100 \mathrm{~mm}$ $\mathrm{x} 100 \mathrm{~mm} \times 500 \mathrm{~mm}$ were cast using the designed mix and cured for 90 days respectively. The cubes and beams were tested for density, water absorption, compressive and flexural strengths in accordance with BS 1881 [26], BS EN 12390: 7 [27], BS EN 12390: 3 [28] and BS EN 12390: 5 [29] specifications respectively.

\subsection{Methods}

\subsubsection{Determination of $\mathrm{EE}$ and $\mathrm{CO}_{2}$ Emission}

The EE and $\mathrm{CO}_{2}$ emission of the concrete samples containing CCA were determined using inventory method of analysis. The main advantage of this method is that it has greater accuracy and flexibility than the other methods and tedious procedures that involve chemical equations are avoided by using emission factors. The $\mathrm{EE}$ and $\mathrm{CO}_{2}$ emission values for various mixes were calculated using the model equations presented in equations $(1,2,3,4,5)$ and (6). The boundary for the EE and $\mathrm{CO} 2$ analysis was 'Cradle to Site'.

$$
\begin{gathered}
\text { Cradle to Site EE = Cradle to Gate EE + Transportation EE } \\
\text { Cradle to Gate EE = Quantity of material } \times \text { EE coefficien }
\end{gathered}
$$

Therefore,

$$
\text { Cradle to Site } \mathrm{EE}=(1+\mathrm{m})\left(\mathrm{Cx}_{\mathrm{c}}+\mathrm{Sx}_{\mathrm{S}}+\mathrm{Ax}_{\mathrm{A}}+\mathrm{Wx}_{\mathrm{W}}+\mathrm{Rx}_{\mathrm{R}}\right)+\mathrm{T}
$$

The $\mathrm{CO}_{2}$ Emission was calculated using:

$$
\begin{gathered}
\text { Cradle to Site } \mathrm{CO}_{2} \text { emission }=\text { Cradle to Gate } \mathrm{CO}_{2} \text { emission }+ \text { Transport } \mathrm{CO}_{2} \text { emission } \\
\text { Cradle to Gate } \mathrm{EE}=\text { Quantity of material } \times \mathrm{CO}_{2} \text { emission factor }
\end{gathered}
$$

Cradle to Site $\mathrm{CO}_{2}$ emission $=(1+\mathrm{m})\left(\mathrm{Cx}_{\mathrm{c}}+\mathrm{Sx}_{\mathrm{S}}+\mathrm{Ax}_{\mathrm{A}}+\mathrm{Wx}_{\mathrm{W}}+\mathrm{Rx}_{\mathrm{R}}\right)+\mathrm{T}$ 
Where $\mathrm{m}$ is the wastage factor $(\%), \mathrm{C}, \mathrm{S}, \mathrm{A}, \mathrm{W}$ and $\mathrm{R}$ (in $\mathrm{Kg}$ ) of cement, sand, aggregate, water, and cement replacement respectively. $\mathrm{T}$ is the transportation energy calculated using equation (11). The parameters $x_{C}, x_{S}, x_{A}, x_{W}$, and $x_{R}$ are the EE coefficients $/ \mathrm{CO}_{2}$ emission per kilogram for the materials mentioned above (Hammond and Jones, 2008).

Generally, waste materials are assumed to have zero EE. Therefore, corn cob has zero EE and $\mathrm{CO}_{2}$ emission at the point of collection in the farm. The CCA is produced using controlled burning in a kiln at temperature of about $450^{\circ} \mathrm{C}$. The process of burning the corncob to produce CCA consumed energy and emitted $\mathrm{CO}_{2}$. Therefore, the EE and $\mathrm{CO}_{2}$ emission of the CCA was calculated from the EE of fuel (Kerosene) used to power the kiln as follows:

10 liters of kerosene was used to power the kiln. Density of kerosene is $780 \mathrm{~kg} / \mathrm{m}^{3}$.

$$
\begin{gathered}
\text { mass of } 10 \text { liters of kerosene }=780 \times\left(10 \times 10^{-3}\right) \\
=7.8 \mathrm{~kg}
\end{gathered}
$$

$$
\mathrm{EE} \text { of kerosene }=3.45 \mathrm{MJ} / \mathrm{kg}
$$

Total EE of burning 10 liters of kerosene $=7.8 \times 3.45$

$$
=26.91 \mathrm{MJ}
$$

Approximately $20 \mathrm{~kg}$ of CCA was obtained from burning of 10 liters of kerosene.

Therefore,

$$
\mathrm{EE} \text { of } \mathrm{CCA}=\frac{26.91}{20}=1.35 \mathrm{MJ} / \mathrm{kg}
$$

Equation (7) shows the relationship between the EE and embodied carbon (EC) equivalent developed by Hammond and Jones [30].

$$
\text { EC equivalent }(\mathrm{kg})=0.021 \times \mathrm{EE}
$$

The EC equivalent was converted to embodied $\mathrm{CO}_{2}$ using equation (8) (Jones, 2010).

$$
\text { EC equivalent }=3.67 \times \mathrm{CO}_{2}(\mathrm{~kg})
$$

Equation (9) was obtained by substituting equation (8) into equation (7) and $\mathrm{CO}_{2}$ was made the subject of the relation.

$$
\text { Embodied } \mathrm{CO}_{2}(\mathrm{~kg})=0.0057 \times \mathrm{EE}
$$

But total EE of CCA was 26.91 MJ,

$$
\begin{gathered}
\text { Therefore, Embodied } \mathrm{CO}_{2}=0.0057 \times 26.91 \\
=0.1534 \mathrm{~kg} \text { of } \mathrm{CO}_{2}
\end{gathered}
$$

The unit $\mathrm{CO}_{2}$ emission per kilogram of CCA was obtained as follows:

$$
\text { Embodied } \mathrm{CO}_{2}=\frac{0.1534}{20}=0.008 \mathrm{~kg} \text { of } \mathrm{CO}_{2} / \mathrm{kg}
$$

Table 2 showed the EE coefficients and $\mathrm{CO}_{2}$ emission factors for the materials. These factors were obtained from the database of Inventory of Carbon and Energy (ICE) developed at the University of Bath.

Table 2. EE coefficient and $\mathrm{CO}_{2}$ emission factors for concrete materials.

\begin{tabular}{lll}
\hline Material & EE coefficient (MJ/kg) & $\mathbf{C O}_{2}$ emission factor (kg CO $\left./ \mathbf{k g}\right)$ \\
\hline Fine aggregate & 0.10 & 0.005 \\
Coarse aggregate & 0.30 & 0.100 \\
Cement & 4.60 & 0.830 \\
CCA & $1.35^{*}$ & $0.008^{*}$ \\
water & 0.00 & 0.000 \\
\hline
\end{tabular}

Sources: Hammond and Jones [15],

calculated using equations [1] to [10].

\subsubsection{Transportation $\mathrm{EE}$ and $\mathrm{CO}_{2}$ Emission}

Transportation of construction materials consume a lot of fuel energies and emit $\mathrm{CO}_{2}$ into the atmosphere. These energies and $\mathrm{CO}_{2}$ are also embodied into the materials. According to Bribian, Capilla \& Uson (2011) EE and $\mathrm{CO}_{2}$ emissions due to transportation of all the materials were calculated using the linear correlation shown in equation (11).
Table 3 shows the values to be applied in order to evaluate the impact of transporting one tonne by various means of transportation, where $d_{i}$ is the distance travelled by the $i$-th mode of the transport (in $\mathrm{km}$ ) and $\mathrm{m}_{\mathrm{i}}$ represents the coefficients applied to the i-th form of transport.

Transport impact $=m_{1} \times d_{1}+m_{2} \times d_{2}+m_{3} \times d_{3}(11)$

Table 3. EE and $\mathrm{CO}_{2}$ emission coefficients for transportation of one tonne of material.

\begin{tabular}{llll}
\hline Impact category & Mode of transportation & & \\
\hline & Road $\left(\mathbf{m}_{\mathbf{1}}\right)$ & Rail $\left(\mathbf{m}_{\mathbf{2}}\right)$ & Ship $\left(\mathbf{m}_{\mathbf{3}}\right)$ \\
\hline Primary energy demand $(\mathrm{MJ} / \mathrm{km})$ & 3.266 & 0.751 & 0.170 \\
$\mathrm{CO}_{2}$ emission $(\mathrm{kg} / \mathrm{km})$ & 0.193 & 0.039 & 0.011 \\
\hline
\end{tabular}

Source: Bribian et al. [31]

Table 4 showed the locations and average haulage distances from point of manufacture or collection of each material to the 
laboratory.

Table 4. Average haulage distances of materials.

\begin{tabular}{llll}
\hline Material & Place of manufacture/collection & Average haulage distance $(\mathbf{k m})$ & Location coordinates \\
\hline Fine aggregate & Bayara village, Bauchi & 10.78 & $10^{\circ} 13^{\prime} 01^{\prime \prime} \mathrm{N}, 9^{\circ} 43^{\prime} 45^{\prime \prime} \mathrm{E}$ \\
Coarse aggregate & Triacta quarry, Bauchi & 6.76 & $10^{\circ} 14^{\prime} 22^{\prime \prime} \mathrm{N}, 9^{\circ} 45^{\prime} 26^{\prime \prime} \mathrm{E}$ \\
Cement & Ashaka, Gombe & 239 & $10^{\circ} 55^{\prime} 44^{\prime \prime} \mathrm{N}, 11^{\circ} 28^{\prime} 29^{\prime \prime} \mathrm{E}$ \\
CCA & Bishi village, Bauchi & 34 & $10^{\circ} 15^{\prime} 09^{\prime \prime} \mathrm{N}, 10^{\circ} 06^{\prime} 12^{\prime \prime} \mathrm{E}$ \\
water & Borehole & 0.0 & $10^{\circ} 16^{\prime} 47^{\prime \prime} \mathrm{N}, 9^{\circ} 47^{\prime} 24^{\prime \prime} \mathrm{E}$ \\
\hline
\end{tabular}

Tables 5 and 6 showed the computations of $\mathrm{EE}$ and $\mathrm{CO}_{2}$ emissions respectively from excel spreadsheets using equations (3, 6 ) and (11) for concrete containing 5\% CCA as OPC replacement.

Table 5. EE of concrete containing 5\% CCA.

\begin{tabular}{llllll}
\hline Material & Mass $(\mathbf{k g})$ & EE coefficient $(\mathbf{M J} / \mathbf{k g})$ & Transportation distance $\mathbf{( k m )}$ & Transportation EE $(\mathbf{M J})$ & Embodied energy $(\mathbf{M J})$ \\
\hline OPC & 5.938 & 4.6 & 239 & 4.635048412 & 31.94984841 \\
CCA & 0.312 & 1.35 & 34.00 & 0.034645728 & 0.455845728 \\
FA & 8.837 & 0.10 & 10.78 & 0.311128501 & 1.194828501 \\
CA & 18.001 & 0.30 & 6.76 & 0.397428958 & 5.797728958 \\
Water & 2.874 & 0.00 & 0.00 & 0 & 0 \\
\multicolumn{2}{l}{ Total Embodied Energy $(\mathrm{MJ})=$} & & & 39.3982516 \\
\hline
\end{tabular}

Table 6. $\mathrm{CO}_{2}$ emission of concrete containing 5\% CCA.

\begin{tabular}{llllll}
\hline Material & Mass $(\mathbf{k g})$ & $\mathbf{C O}_{2}$ emission factor $\left(\mathbf{k g} \mathbf{C O}_{2} / \mathbf{k g}\right)$ & Transportation distance $(\mathbf{k m})$ & Transportation $\mathbf{C O}_{2} \mathbf{~ e m i s s i o n ~}(\mathbf{k g})$ & $\mathbf{C O}_{2} \mathbf{~ e m i s s i o n ~}(\mathbf{k g})$ \\
\hline OPC & 5.938 & 0.83 & 239 & 0.273902126 & 5.202442126 \\
$\mathrm{CCA}$ & 0.312 & 0.008 & 34.00 & 0.002047344 & 0.004543344 \\
$\mathrm{FA}$ & 8.837 & 0.005 & 10.78 & 0.018385732 & 0.062570732 \\
$\mathrm{CA}$ & 18.001 & 0.017 & 6.76 & 0.023485545 & 0.329502545 \\
Water & 2.874 & 0.00 & 0.00 & 0 & 0 \\
\multicolumn{2}{l}{ Total $\mathrm{CO}_{2}$ Emission $(\mathrm{Kg})=$} & & & 5.599058747 \\
\hline
\end{tabular}

\section{Results and Discussion}

\subsection{Mechanical Properties}

The results of mechanical properties of concrete cured at 90 days is presented in Table 7. Generally the densities decreased with increase in CCA content. The density decreased from $2473 \mathrm{~kg} / \mathrm{m}^{3}$ at $0 \%$ CCA content to 2397 $\mathrm{kg} / \mathrm{m}^{3}$ at $20 \% \mathrm{CCA}$ content. These lie within the range of 2200 to $2600 \mathrm{~kg} / \mathrm{m}^{3}$ specified as the density of normal weight concrete [32]. Also, the water absorptions decreased with increase in CCA contents. The low range of water absorption obtained is as a result of a less permeable calcium silicate hydrate (C-S-H) produced when $\mathrm{SiO}_{2}$ from CCA reacted with $\mathrm{Ca}(\mathrm{OH})_{2}$ from cement [33]. The lower the water absorption of concrete the more durable is the concrete. Durability of concrete is improved by decreasing its porosity and transport properties [34]. The results also show decrease in compressive and flexural strengths with increase in CCA contents. The optimum blend was obtained at $10 \% \mathrm{CCA}$ and $90 \%$ OPC contents with compressive strength value of 30.17 $\mathrm{N} / \mathrm{mm}^{2}$. This agrees with the findings of other researchers [35, 10] and [36]. This strength gain can be attributed to the cementitious products formed as a result of hydration of cement and those formed when lime reacts with the pozzolana incorporated [37]

Table 7. Mechanical properties of concrete at 90 days curing.

\begin{tabular}{lllll}
\hline Mix no. & Density $\left(\mathbf{k g} / \mathbf{m}^{\mathbf{3}}\right)$ & Water Absorption $\mathbf{~ \% )}$ & Flexural Strength $\mathbf{( N / \mathbf { m m } ^ { 2 } )}$ & Compressive Strength $\left(\mathbf{N} / \mathbf{m m}^{2}\right)$ \\
\hline CCA-00 & 2473 & 3.21 & 5.85 & 32.85 \\
CCA-05 & 2437 & 2.57 & 5.49 & 29.05 \\
CCA-10 & 2416 & 2.10 & 5.64 & 30.17 \\
CCA-15 & 2408 & 1.93 & 4.77 & 24.56 \\
CCA-20 & 2397 & 1.80 & 4.32 & 20.68 \\
\hline
\end{tabular}

Table 8. Embodied energy.

\begin{tabular}{lllllllll}
\hline Mix no. & OPC $(\mathbf{k g})$ & CCA $(\mathbf{k g})$ & FA $(\mathbf{k g})$ & CA $(\mathbf{k g})$ & Water $(\mathbf{k g})$ & Embodied energy $(\mathbf{M J})$ & Embodied energy $\left(\mathbf{M J} / \mathbf{m}^{3}\right)$ & Embodied energy saved $(\%)$ \\
\hline CCA-00 & 6.250 & 0.000 & 8.837 & 18.001 & 2.874 & 40.6211 & 2708 & 0.0000 \\
CCA-05 & 5.938 & 0.312 & 8.837 & 18.001 & 2.874 & 39.3983 & 2627 & 3.0105 \\
CCA-10 & 5.626 & 0.624 & 8.837 & 18.001 & 2.874 & 38.1754 & 2545 & 6.0210 \\
CCA-15 & 5.314 & 0.936 & 8.837 & 18.001 & 2.874 & 36.9525 & 2464 & 9.0315 \\
CCA-20 & 5.002 & 1.248 & 8.837 & 18.001 & 2.874 & 35.7296 & 2382 & 12.0419 \\
\hline
\end{tabular}




\subsection{Embodied Energy}

The results of EE of concrete containing CCA were presented in Table 8. The table showed the quantities of materials in kilogram required to produce the batch of fifteen sample cubes, their EE in Mega Joule, the EE per cubic meter of concrete and the percentage of EE saving of the CCA. The results indicated that the EE decreases with increase in CCA contents.

Figure 2 shows the plot of the variation of EE with CCA contents. The EE decreased from $40.6211 \mathrm{MJ}\left(2708 \mathrm{MJ} / \mathrm{m}^{3}\right)$ at $0 \%$ CCA content to $35.7296 \mathrm{MJ}\left(2382 \mathrm{MJ} / \mathrm{m}^{3}\right)$ at $20 \%$ CCA content. At $10 \%$ CCA content the percentage decease in EE of the concrete is $6.02 \%$ while at $20 \%$ CCA content is $12.04 \%$. The high percentage of EE saving obtained indicates that OPC is the major contributor of the concrete EE. The regression model for the relationship between EE and CCA contents is presented in equation (12).

$$
E E_{c}=40.62-0.2446 C C A
$$

Table 9 shows the results of regression analysis of EE. The standard deviation, $\mathrm{S}=7.4388 \times 10^{-15}$. The T-statistics are $1.5764 \times 10^{16}$ and $1.1625 \times 10^{15}$ for constant and CCA terms respectively. These values are greater than the T-critical $\left(\mathrm{T}_{24}\right.$, $0.05=1.711$ ) at $5 \%$ level of significance. The probability of the t-statistic, $\mathrm{P}=0.0000$ for the constant and CCA terms which is less than the P-value (0.05). All these show that there is good relationship between the CCA content and the $\mathrm{EE}$ and the model equation is a good predictor of the response $\left(\mathrm{EE}_{\mathrm{c}}\right)$.
Table 10 shows the results of ANOVA for the EE of the concrete. The results show the effect of CCA on EE of the concrete at $5 \%$ level of significance The F-statistic is 1.4916 $\mathrm{x} 10^{06}$ for both the constant and CCA terms. The value is greater than the $\mathrm{F}$-critical $(\mathrm{F} 1,23,0.05=4.28)$. The probability of the F-statistic, $\mathrm{P}=0.0000$ for the constant and CCA terms which is less than the P-value $(0.05)$. These show that the variation in $\mathrm{EE}$ of the concrete is associated with the variation in CCA contents.

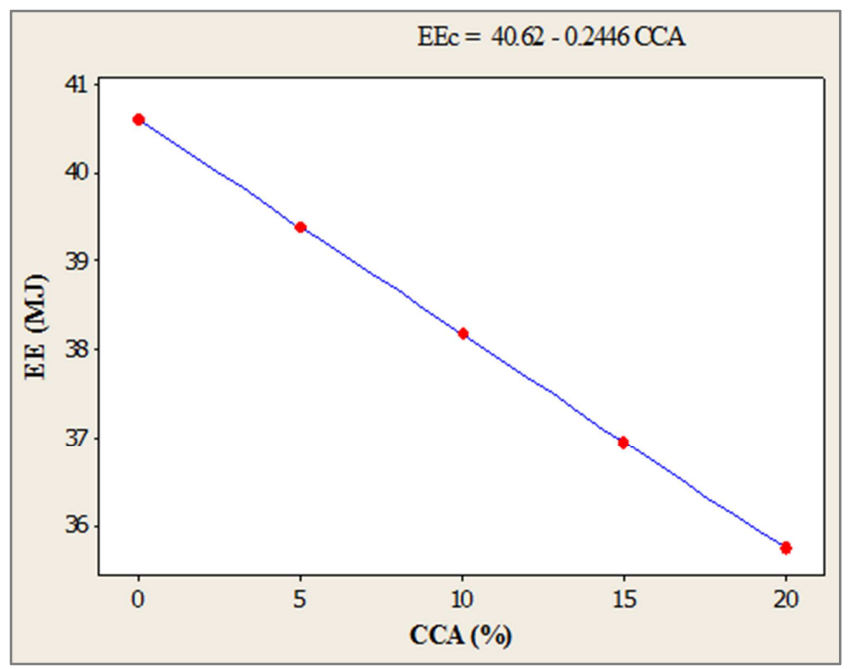

Figure 2. Variation of EE (MJ) with CCA (\%).

Table 9. Regression analysis for EE of concrete.

\begin{tabular}{llllll}
\hline Term & Coefficient & SE Coefficient & T & P & Relationship \\
\hline Constant & 40.6211 & 0.0000 & 1.5764 E16 & 0.0000 & Significant \\
CCA & -0.2446 & 0.0000 & -1.1625 E15 & 0.0000 & Significant \\
S=7.4388 E-15 & & & & & \\
\hline
\end{tabular}

Table 10. ANOVA for the EE of concrete at $5 \%$ level of significance.

\begin{tabular}{llllllll}
\hline Source & DF & Seq SS & Adj SS & Adj MS & F & P & Effect \\
\hline Regression & 1 & 74.7734 & 74.7734 & 74.7734 & 1.4916 E06 & 0.0000 & Significant \\
CCA & 1 & 74.7734 & 74.7734 & 74.7734 & 1.4916 E06 & 0.0000 & Significant \\
Error & 23 & 0.0000 & 0.0000 & 0.0000 & & & \\
Total & 24 & 74.773 & & & & & \\
\hline
\end{tabular}

\subsection{Embodied Carbon IV Oxide Emission}

The results of $\mathrm{CO}_{2}$ emission of concrete containing CCA were presented in Table 11. The table presented the quantities of the materials in kilogram required to produce the batch of fifteen sample cubes, their $\mathrm{CO}_{2}$ emission in kilogram, the $\mathrm{CO}_{2}$ emission per cubic meter of concrete and the percentage of $\mathrm{CO}_{2}$ emission saving of the CCA.

Table 11. Embodied carbon IV oxide emission.

\begin{tabular}{lllllllll}
\hline MIX NO. & OPC (Kg) & CCA (Kg) & FA (Kg) & $\mathbf{C A}(\mathbf{K g})$ & Water $(\mathbf{K g})$ & $\mathbf{C O}_{2}$ Emission $(\mathbf{K g})$ & $\mathbf{C O}_{2}$ Emission $\left(\mathbf{K g} / \mathbf{m}^{3}\right)$ & $\mathbf{C O}_{2}$ Emission Saved (\%) \\
\hline CCA-00 & 6.250 & 0.000 & 8.837 & 18.001 & 2.874 & 5.8679 & 391.2 & 0.0000 \\
CCA-05 & 5.938 & 0.312 & 8.837 & 18.001 & 2.874 & 5.6278 & 375.2 & 4.0918 \\
CCA-10 & 5.626 & 0.624 & 8.837 & 18.001 & 2.874 & 5.3877 & 359.2 & 8.1837 \\
CCA-15 & 5.314 & 0.936 & 8.837 & 18.001 & 2.874 & 5.1476 & 343.2 & 12.2755 \\
CCA-20 & 5.002 & 1.248 & 8.837 & 18.001 & 2.874 & 4.9075 & 327.2 & 16.3674 \\
\hline
\end{tabular}

The results indicated that the $\mathrm{CO}_{2}$ emission decreases with increase in CCA contents. Figure 3 shows the graph of 
variation of $\mathrm{CO}_{2}$ emission with $\mathrm{CCA}$ contents. The values of $\mathrm{CO}_{2}$ emissions obtained per 15 cubes are $5.8679 \mathrm{~kg}, 5.6278$ $\mathrm{kg}, 5.3877 \mathrm{~kg}, 5.1476 \mathrm{~kg}$ and $4.90756 \mathrm{~kg}$ for $0,5,10,15$ and $20 \%$ CCA contents, which were equivalent to $391.2 \mathrm{~kg} / \mathrm{m}^{3}$, $375.2 \mathrm{~kg} / \mathrm{m}^{3}, 359.2 \mathrm{~kg} / \mathrm{m}^{3}, 343.2 \mathrm{~kg} / \mathrm{m}^{3}$ and $327.2 \mathrm{~kg} / \mathrm{m}^{3}$ respectively. At $20 \% \mathrm{CCA}$ contents the $\mathrm{CO}_{2}$ emission was lower than that of the control concrete by $16.37 \%$. This indicates that OPC is the major contributor of concrete's $\mathrm{CO}_{2}$ emission. The regression model for the relationship between $\mathrm{CO}_{2}$ emission and CCA content is presented in equation (13).

$$
\mathrm{CO}_{2 c}=5.868-0.05376 C C A
$$

The regression results for the relationship between $\mathrm{CO}_{2}$ emission and CCA content are presented in Table 12. The standard deviation of error in the model, $\mathrm{S}=7.861 \times 10^{-09}$. The T-statistics are $2.155 \times 10^{09}$ and $2.418 \times 10^{08}$ for constant and CCA terms respectively. These values are greater than the Tcritical $(\mathrm{T} 24,0.05=1.711)$ at $5 \%$ level of significance. The probability of the T-statistic, $\mathrm{P}=0.000$ for the constant and CCA terms which is less than the P-value (0.05). All these show that there is an excellent linear relationship between the $\mathrm{CO}_{2}$ emission and CCA content, and therefore CCA is a useful predictor of the regression model.
Table 13 shows the results of ANOVA for the $\mathrm{CO}_{2}$ emission of the concrete. The results show the effect of CCA on the $\mathrm{CO}_{2}$ emission of the concrete at $5 \%$ level of significance. The F-statistic is $5.846 \times 10^{16}$ which is greater than the F-critical $(\mathrm{F} 1,23,0.05=4.28)$. The probability of the F-statistic, $\mathrm{P}=0.00$ which is less than the $\mathrm{P}$-value (0.05). These show that the CCA content has significant effect in variation of $\mathrm{CO}_{2}$ emission of the concrete.

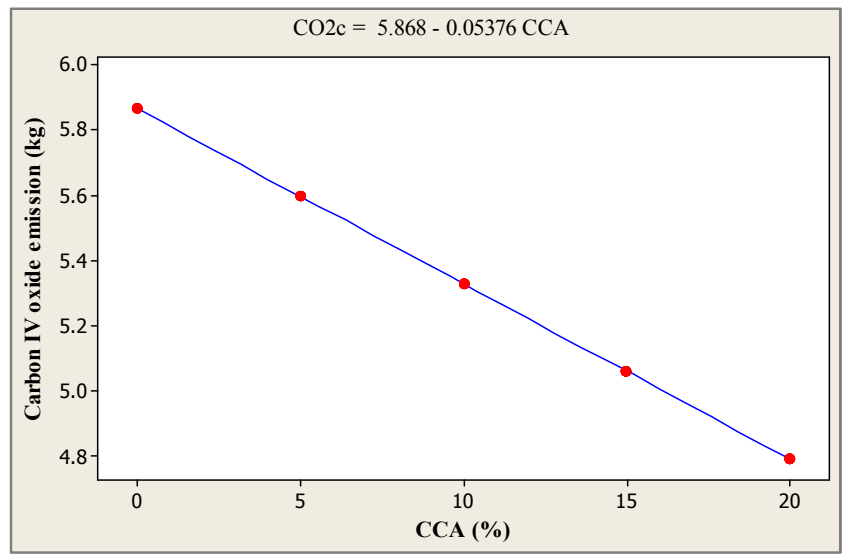

Figure 3. Variation of $\mathrm{CO}_{2}$ Emission ( $\left.\mathrm{kg}\right)$ with $\mathrm{CCA}(\%)$.

Table 12. Regression analysis for $\mathrm{CO}_{2}$ emission of concrete.

\begin{tabular}{lllll}
\hline Predictor & Coefficient & SE coefficient & T & P \\
\hline Constant & 5.8679 & 0.0000 & 2.1547 E9 & 0.0000 \\
CCA & -0.05376 & 0.0000 & -2.4178 E8 & 0.0000 \\
S=7.8616 E-09 & & & & Significant \\
\hline
\end{tabular}

Table 13. ANOVA for the $\mathrm{CO}_{2}$ emission of concrete at $5 \%$ level of significance.

\begin{tabular}{llllllll}
\hline Source & DF & Seq SS & Adj SS & Adj MS & F & P \\
\hline Regression & 1 & 3.6126 & 3.6126 & 3.6126 & 5.8456 E16 & 0.0000 & Significant \\
CCA & 1 & 3.6126 & 3.6126 & 3.6126 & 5.8456 E16 & Significant \\
Error & 23 & 0.0000 & 0.0000 & 0.0000 & & \\
Total & 24 & 3.6126 & & & & \\
\hline
\end{tabular}

\section{Summary, Conclusion and Recommendation}

\subsection{Summary}

The EE and $\mathrm{CO}_{2}$ emission analysis of concrete containing CCA was explored. The CCA was proven to reduce the EE and $\mathrm{CO}_{2}$ emission of the concrete. Empirical relations that relate $\mathrm{EE}, \mathrm{CO}_{2}$ emission and $\mathrm{CCA}$ contents were developed using Minitab Statistical Software. The performance of the models was tested using ANOVA.

\subsection{Conclusion}

Based on the results of this research work the following conclusions can be drawn:

1. The use of CCA to replace OPC in concrete has the potential to reduce its EE. The energy savings increased with increase in CCA contents. Concrete containing 20\%
CCA have $12.04 \%$ EE saving.

2. The CCA also has the potential to reduce the $\mathrm{CO}_{2}$ emission of the concrete. At $20 \%$ CCA content the $\mathrm{CO}_{2}$ emission savings was $16.37 \%$.

3. The compressive and flexural strength decreased with increase in CCA contents. The optimum blend was obtained at $10 \%$ CCA and $90 \%$ OPC contents.

4. The CCA increased the durability of concrete by decreasing its water absorption.

5. The empirical relations developed provided very good prediction of the response. The developed equations were as follows:

$$
\begin{gathered}
E E_{c}=40.62-0.2446 C C A \\
\mathrm{CO}_{2 c}=5.868-0.05376 C C A
\end{gathered}
$$

6. The P-values for the regression models were less than 0.05 which indicate that there is good relationship between the predictors and the responses. The calculated T-statistics exceeded the T-critical (T24, 
$0.05=1.711)$ at $5 \%$ level of significance.

7. The calculated F-statistics exceeded the F-critical (F1, 23, $0.05=4.28$ ) at $5 \%$ level of significance. These indicate that the CCA content has significant effect in the reduction of the $\mathrm{EE}$ and $\mathrm{CO} 2$ emission of the concrete.

\subsection{Recommendation}

Based on the results obtained from this study, CCA is recommended for use as cement replacement in mitigating $\mathrm{EE}$ and $\mathrm{CO}_{2}$ emission of concrete. With regards to mechanical properties, not more than $10 \%$ CCA content is recommended as cement replacement in concrete.

\section{References}

[1] OECD (2003). Environmental sustainable building challenges and policies. Organisation for Economic Co-operation and Development (OECD). Paris.

[2] Lomite, H. (2009). Impact of Construction Material on Environment. Unpublished Master's Thesis, University of Boras.

[3] Joseph, P. \& Nally, S. M. (2010). Sustainable Non-Metallic Building Materials. Sustainability. 2, 400-427.

[4] Shubbar, A., Jafer, H. M., Dulaimi, A., Atherton, W., \& AlRifaie, A. (2017). The Development of a Low Carbon Cementitious Material Produced from Cement, Ground Granulated Blast Furnace Slag and High Calcium Fly Ash. International Journal of Civil, Environmental, Structural, Construction and Architectural Engineering, 11 (7).

[5] Hasanbeigi, A., Price, L. \& Lin, E., (2012). Emerging energy efficiency and $\mathrm{CO}_{2}$ emission reduction technologies for cement and concrete production. A technical review. Renewable Sustainable Energy Rev., 16, 6220-6238.

[6] Olivier J. G. J., Janssens-Maenhout G., Muntean M. \& Peters J. A. H. W. (2016), Trends in global CO2 emissions; 2016 Report, The Hague: PBL Netherlands Environmental Assessment Agency; Ispra: European Commission, Joint Research Centre.

[7] González M. \& Navarro J. (2006). Assessment of the Decrease of $\mathrm{CO}_{2}$ Emissions in the Construction Field Through the Selection of Materials: Practical Case Study of Three Houses of Low Environmental Impact. Build Environ. 41, 902-909.

[8] UNCHS, (1991). Energy for Building - Improving Energy Efficiency in Construction and in the Production of Building Materials in Developing Countries. United Nation Centre for Human Settlements Publication. Nairobi.

[9] Adesanya, D. A. (1996). Evaluation of Blended Cement Mortar, Concrete and Stabilized Earth made from Ordinary Portland Cement and Corn Cob Ash. Construction and Building Materials. 10 (6), 451-456.

[10] Adesanya, D. A. \& Raheem, A. A. (2009). Development of Corn Cob Ash Blended Cement. Construction and Building Materials. 23, 347-352.

[11] Sintayehu, A., \& Mamaru, D. (2019). Production of Lightweight Concrete Using Corncob Ash as Replacement of
Cement in Concrete. American Journal of Civil Engineering, 7 (1), 17-20. doi: 10.11648/j.ajce.20190701.13

[12] Milne, G. \& Reardon, C. (2008). Embodied energy, inYour Technical Manual. Retrieved December 12, 2009. From: http://www.yourhome.gov.au/technical/fs52.html

[13] Dixit, M. K., Fernandez, J. L., Lavy, S. \& Culp, C. H. (2010). Identification of parameters for embodied energy measurement: A literature review. Energy and Buildings. 42 (8), 1238-1247.

[14] Gustavsson, L. \& Sathre, R. (2004). Embodied Energy and $\mathrm{CO} 2$ Emission of Wood and Concrete Framed Buildings in Sweden. Second World Conference on Biomass for Energy. Industry and Climate Protection. Rome Italy. 10-14.

[15] Hammond, G. P. \& Jones, C. I. (2008). Embodied energy and carbon in construction materials. Proceedings of the Institution of Civil Engineers-Energy. 161 (2), 87-98.

[16] Hammond G. P. \& Jones C. I. (2011). Inventory of (embodied) Carbon \& Energy Database (ICE), Version 2.0, UKUniversity of Bath.

[17] Berndt, M. L. (2009). Properties of Sustainable Concrete Containing Fly Ash, Slag and Recycled Concrete Aggregate. Construction and building materials. 23, 2606-2613.

[18] BS EN 196 (1995). Methods of testing cement-Part 3: Determination of setting time and soundness. British Standard Specification. London.

[19] BS EN 197 (1992). Cement-Part 1: Composition, specifications and conformity criteria for common cements. British Standard Specification. London.

[20] BS EN 1097 (2000). Tests for mechanical and physical properties of aggregates-Part 6: Determination of Particle Density and Water Absorption. British Standard Specification. London.

[21] BS 812 (1995). Testing Aggregates-Part 2: Methods of Determination of Density, British Standard Specification. London.

[22] BS 812 (1990). Testing Aggregates-Part 110: Methods for determination of aggregate crushing value (ACV). British Standard Specification. London.

[23] BS EN 933 (1997). Determination of Particle Size Distribution-Part 1: Sieving Method. British Standard Specification. London.

[24] BS EN 12390 (2000). Testing hardened concrete-Part 1: Shape, dimensions and other requirements for specimens and moulds. British Standard Specification. London.

[25] BS EN 12390 (2000). Testing hardened concrete-Part 2: Making and curing specimens for strength tests. British Standard Specification. London.

[26] BS 1881 (1983). Testing concrete-Part 122: Method for determination of water absorption. British Standard Specification. London

[27] BS EN 12390 (2000). Testing hardened concrete-Part 7: Density of hardened concrete. British Standard Specification. London.

[28] BS EN 12390 (2002). Testing hardened concrete-Part 3: Compressive strength of test specimens. British Standard Specification. London. 
[29] BS EN 12390 (2000). Testing hardened concrete-Part 5: Flexural strength of test specimens. British Standard Specification. London.

[30] Hammond, G. P. \& Jones, C. I., (2007). Benchmarks for Embodied Energy \& Carbon: Domestic Buildings. In Proc. of the International Conference of the Society for Sustainability and Environmental Engineering 07 (SSEE 07), Perth, Australia.

[31] Bribian, I. Z., Capilla, A. V. \& Uson, A. A. (2011). Life cycle assessment of building materials: Comparative analysis of energy and environmental impact and evaluation of the ecoefficiency improvement potential. Building and Environment. $46,1133-1140$.

[32] Neville, A. M. (2000). Properties of Concrete, 4th edition, England; Longman.

[33] Kamau, J., \& Ahmed, A. (2017). A Review of the Use of Corncob Ash as a Supplementary Cementitious Material. EJERS, European Journal of Engineering Research and

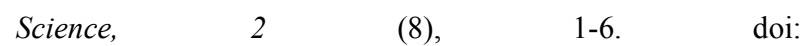
http://dx.doi.org/10.24018/ejers.2017.2.8.415

[34] Vanwalleghem, H., Blontrock, H., \& Taerwe, L. (2003). Spalling tests on self-compacting concrete. In O. Wallevik, and I. Nielsson (Ed.), Proceedings of the Third International Symposium on Self-compacting Concrete. RILEM Publications, Bagneux, France. 855-862.

[35] Udoeyo, F. F., \& Abubakar, S. A. (2003). Maize-cob ash as filler in concrete. Journal of materials in civil engineering, 205-208.

[36] Singh, K., Singh, J., \& Kumar, S. (2017). A Sustainable Environmental Study on Corn Cob Ash Subjected To Elevated Temperature. Current World Environment, 13 (1), 144-150. Retrieved from www.cwejournal.org

[37] Balendran, R. V. \& Martin-Buades, W. H. (2000). The Influence of High Temperature Curing on the Compressive, Tensile and Flexural Strength of Pulverized Fuel Ash Concrete. Building and Environment. 35 (5), 415-423. 